\title{
Kalp Yetersizliği Hastalarına Bakım Veren Aile Üyelerinde Algılanan Bakım Yükü ve Etkileyen Faktörler
}

\author{
Zehra Gök Metin, Aylin Helvacı
}

Hacettepe Üniversitesi Hemşirelik Fakültesi, İç Hastalıkları Hemşireliği Anabilim Dalı, Ankara

\begin{abstract}
Özet
Amaç: Bu araştırma kalp yetersizliği (KY) hastalarına bakım veren aile üyelerinde bakım verme yükünü ve etkileyen faktörleri belirlemek amacıyla planlandı.

Yöntemler: Tanımlayıcı kesitsel türdeki bu araştırma, Ankara ilinde bir üniversite hastanesinde takip edilen KY tanılı hastalar ( $n=100)$ ve bu hastalara bakım veren aile üyeleri $(n=100)$ ile Aralık 2018-Mayıs 2019 tarihleri arasında yürütüldü. Araştırma verilerinin toplanmasında "Hasta Bilgi Formu”, “Bakım Veren Bilgi Formu” ve "Zarit Bakım Verme Yükü Ölçeği (ZBYÖ)" kullanıldı. Verilerin analiz edilmesi için tanımlayıcı istatistikler, Ki-kare testi ve Pearson Korelasyon testlerinden yararlanıldı.

Bulgular: Araştırmaya dahil olan KY hastalarının \%55'inin erkek, \%85'inin ilkokul mezunu, \%71'nin evli ve \%38'inin evre $2 \mathrm{KY}$ tanısı olduğu belirlendi. Hastaların yaş ortalamasının $66.76 \pm 12.43$ olduğu görüldü. Araştırmaya dahil olan bakım veren aile üyelerinin \%70'inin kadın, \%77'sinin ilkokul mezunu, \%99'unun evli ve yaş ortalamasının $50.74 \pm 12.68$ yıl olduğu belirlendi. Bakım veren aile üyelerinin ZBYÖ puan ortalaması $13.71 \pm 6.89$ şeklinde hesaplandı. Eğitim seviyesi ve gelir durumu düşük, çalışmayan, 8 yıldan uzun süredir ve günde 5 saatten fazla bakım veren aile üyelerinin algıladıkları bakım yükünün anlamlı düzeyde yüksek olduğu bulundu $(p<0.05)$. Ayrıca, hastaların KY tanı süresi, KY evresi ve eşlik eden komorbid durumları ile algılanan bakım yükü puanları arasındaki farkın istatistiksel açıdan anlamlı olduğu belirlendi $(p<0.05)$.

Sonuç: Araştırmamızda KY hastalarına bakım veren aile üyelerinin algıladıkları bakım yükünün düşük düzeyde olduğu bulundu. KY hastalarına bakım veren aile üyelerini hedef alan ilerideki araştırmaların eğitim seviyesi ve gelir durumu düşük, işsiz ve uzun süredir bakım veren bireylerin gereksinimlerine odaklanması önerildi.
\end{abstract}

Anahtar sözcükler: Bakım veren; bakım veren yükü; kalp yetersizliği; Türkiye.

Perceived Caregiver Burden and Associated Factors Among Family Caregivers Providing Care for Heart Failure Patients

\footnotetext{
Abstract

Objective: The purpose of the study was to assess caregiver burden and associated factors in family caregivers providing care for heart failure (HF) patients.

Methods: This descriptive, cross-sectional study was conducted with HF patients $(n=100)$ followed in a university hospital located in Ankara and their family caregivers ( $n=100)$ between December 2018 and May 2019. Data were measured using "The Patient Information Form"," The Family Caregiver Information Form", and "Zarit Burden Interview". Descriptive statistics, Chi-Square test and Pearson correlation test were utilized for data analysis.
}

İletişim (Correspondence): Dr. Zehra Gök Metin. Hacettepe Üniversitesi Hemşirelik Fakültesi, Altındağ 06100, Ankara, Turkey Telefon (Phone): +90 5448741740 E-Posta (E-mail): zehragok85@hotmail.com

Başvuru Tarihi (Submitted Date): 17.05.2019 Kabul Tarihi (Accepted Date): 10.09.2019 
Results: The patients with HF were male (55\%), had graduated from primary school (85\%), were married (71\%) and 38\% of those had stage II HF. The mean age of HF patients was $66.76 \pm 12.43$ years. The family caregivers included in this study were female (70\%), had graduated from primary school (77\%), and were married (99\%). The mean age of family caregivers was $50.74 \pm 12.68$ years. The mean score of Zarit Burden Interview was $13.71 \pm 6.89$ in family caregivers. Family caregivers with less education, lower income level, were unemployed and were providing care longer than 8 years, and more than 5 hours per day experienced significantly higher caregiver burden $(p<.05)$. Besides, since time diagnosis for HF, HF stage and comorbid conditions were significantly associated with perceived caregiver burden $(p<0.05)$.

Conclusion: The caregiver burden among family caregivers providing care for HF patients was found low in our study. Future studies targeting family caregivers of HF patients should focus on the needs of individuals with less educated, lower income level, unemployed and providing care for longer time.

Keywords: Caregiver; caregiver burden; heart failure, Turkey.

Cite this article as: Gök Metin Z, Helvacı A. Perceived Caregiver Burden and Associated Factors Among Family Caregivers Providing Care for Heart Failure Patients. Turk J Cardiovasc Nurs 2019;10(22):59-66.

$\mathrm{K}^{\mathrm{rom}}$ ronik, ilerleyici ve yaygın bir hastalık olan kalp yetersizliği $(K Y)$, günümüzde mortalite ve morbiditenin önemli nedenleri arasında yer almaktadır. ${ }^{[1-3]}$ Kalp yetersizliği hastalarında dispne, yorgunluk, ödem, fiziksel kapasitede sınırlılık, uyku sorunları, anksiyete ve depresyon gibi semptomlar sıklıkla görülmektedir. ${ }^{[4-7]}$ Hastalığın ilerlemesiyle semptom yükünde artma, tekrarlı hastane yatışları, iş yaşamındaki sınırlılıklar, cinsel yaşamda olumsuz etkilenme, sosyal ilişkilerde ve manevi iyilik halinde zayıflama, kullanılan tedavilere bağlı gelişen yan etkiler, yaşam tarzında yapılması gereken değişikliklere uyum sağlamada yaşanan zorluklar dolayısıyla hastaların yaşam kalitesinde bozulma görülmektedir. ${ }^{[4,7-9]}$

Kalp yetersizliği tanı aşamasından itibaren uzun bir bakım süreci gerektirmesi nedeniyle, hastalar kadar hastalara bakım veren aile üyelerini de etkilemektedir. ${ }^{[10-13]}$ Genellikle ülkemizde hasta bireyin bakımı aile üyeleri tarafından verilmekte ve bakım verme, aile içi sorumluluk olarak algılanmaktadır. Bakım veren haline gelme seçilemez ve kaçınılmaz bir durum olarak aniden ortaya çıktığından, bakım verenlerin bu duruma uyum sağlamaları oldukça zorlaşmaktadır. ${ }^{[12-16]}$ Böylelikle bu uzun ve zorlu süreçte bakım verme, bakım veren aile üyeleri açısından çok boyutlu olarak algılanmakta ve bakım veren aile üyeleri üzerinde fiziksel, psikolojik, sosyal, ekonomik ve manevi yönden önemli sorunlara yol açmakta, yoğun stres ile birlikte yük haline dönüşebilmektedir. ${ }^{[13,17-20]}$ Literatürde yük kavramı, "bakım veren bireylerin, üstlendiği bakımın ortaya çıkardığı, psikolojik sıkıntı, fiziksel sağlık problemleri, ekonomik problemler, sosyal problemler, aile ilişkilerinin bozulması ve kontrolün kendisinde olmadığı duygusunu yaşamak gibi olumsuz objektif ve subjektif sonuçlar" şeklinde açıklanmaktadır. ${ }^{[19,21]}$

Günümüze kadar farklı kronik hastalık gruplarında bakım verme yüküne odaklanan çalışmalarda, genellikle bakım veren aile üyelerinin bakım verme süreci içerisinde kendi fiziksel ve emosyonel gereksinimlerini ihmal edebildikleri ve tükenmişlik yaşayabildikleri rapor edilmiştir. ${ }^{[13-15]}$ Tükenmişlik yaşayan bakım veren aile üyelerinde zamanla irritabilite, depresyon, baş ağrısı, bitkinlik, diğer fiziksel semptomlar, yeme şeklinde değişiklik, madde kullanımı gibi olumsuz durumlar gelişebilmektedir. ${ }^{[14,20]}$ Bu durumlara ek olarak, bakım verme süreci, bakım veren aile üyelerinde psikiyatrik morbiditede artış, sosyal ilişkilerde bozulma ve emosyonel açıdan da sıkıntılara neden olabilmektedir. ${ }^{[20,}$ 22] Sosyal desteğin az olması, kurumlardan alınan hizmetlerin yetersizliği, akut durumlar, tekrarlı hastane yatışları ve ağır semptom yükü gibi konularla nasıl baş edilmesi gerektiğini bilmeyen bakım verenlerde ise bakım verme zamanla yük haline gelebilmektedir. ${ }^{[17,20,23,24]}$ Ayrıca, bakım verdiği hastanın tanı süresi, evresi, eşlik eden komorbid durumları, tekrarlı hastane yatışları, geçirilen ameliyatlar gibi faktörler ile bakım veren aile üyelerinin eğitim durumu, cinsiyeti, fiziksel kapasitesi, gelir durumu ve bakım verme süresi gibi değişkenler de algılanan bakım verme yükünü önemli şekilde etkileyebilmektedir. ${ }^{[10,14,17,22,24]}$

Kalp yetersizliğinin oluşturduğu önemli morbidite ve mortalite ele alındığında, özellikle hastalığın doğası, prognozda belirsizlikler, ani değişimler, giderek artan semptom yükü, tekrarlı hastane yatışları ve primer bakım veren aile üyelerinin bu süreçte yaşadıkları zorlukların ele alınması önemli bir gerekliliktir. ${ }^{[11,12,15,16,18]}$ Literatür incelendiğinde ise, KY popülasyonunda, özellikle primer bakım verici olan aile üyelerinde bakım verme yükünü ve etkileyen faktörleri inceleyen sınırlı sayıda çalışma bulunmaktadır. ${ }^{[15,18,23]} \mathrm{Bu}$ nedenle, bu araştırma KY hastalarına bakım veren aile üyelerinde bakım verme yükünü ve etkileyen faktörleri belirlemek amacıyla planlanmıştır. Bu araştırma ile KY hastalarına bakım veren aile üyelerinin algıladıkları bakım verme yükü ve bu durumu etkileyen faktörlerin belirlenmesi ile alana önemli katkı sağlanacağı düşünülmüştür. Bakım verme yükünü etkileyen sosyo-demografik özelliklerin belirlenmesi 
ile özellikle bakım verme yükünü yüksek düzeyde algılayan bakım verenlere yönelik destek programları oluşturulabilecek, gerekli eğitim ve danışmanlık sağlanabilecektir.

\section{Gereç ve Yöntem}

Araştırmanın Türü: Bu araştırma tanımlayıcı ve kesitsel tasarımla yürütüldü.

Araştırmanın Yeri ve Zamanı: Araştırma verileri, Ankara'da bulunan bir üniversite hastanesinin Kardiyoloji ve Dahiliye Kliniklerinde 20 Aralık 2018-3 Mayıs 2019 tarihleri arasında toplandı.

Araştırmanın Evren ve Örneklemi: Araştırmanın yapıldığı kliniklerde $K Y$ tanısı ile takip edilen hastalara bakım veren aile üyeleri bu çalışmanın evrenini oluşturdu. Araştırma örneklemini ise iletişime girme sorunu olmayan, 18 yaş ve üzerinde olan, KY hastasına en az 6 aydır bakım vermekte olan ve araştırmaya katılmayı kabul eden aile üyeleri oluşturdu. Yukarıda verilen dahil edilme kriterlerinden herhangi birine uymayan, psikiyatrik bozukluk tanısı olan, bakım hizmetini ücret karşılığı veren ve araştırmaya katılmak istemeyen bakım verenler araştırmaya dahil edilmedi. Örneklem büyüklügünü belirlemek için, araştırma verileri kullanılarak $G^{*}$ Power 3.1 yazııım programı yardımıyla $\alpha=0.05$, bakım verme süresi ve Zarit Bakım Verme Yükü Ölçeği (ZBYÖ) arasındaki korelasyon (0.30) olarak temel alındığında araştırmanın gücü \%90 şeklinde hesaplandı. Bu kapsamda, araştırmanın örneklemine KY tanılı 100 hasta ve bu hastalara bakım veren 100 aile üyesi olmak üzere toplam 200 kişi dahil edildi.

Veri Toplama Araçları: Araştırmada literatür taranarak araştırmacılar tarafından geliştirilen "Hasta Bilgi Formu", "Bakım Veren Bilgi Formu" ve bakım yükünü değerlendirmek için ZBYÖ kullanıldı.

Hasta Bilgi Formu: Literatür taranarak geliştirilen bu formda hastaların sosyo-demografik ve klinik özelliklerini belirlemek hedeflendi. Sosyo-demografik özellikler açısından hastaların yaşı, cinsiyeti, eğitim durumu, medeni durumu, gelir durumunu içerene beş soru, hastanın klinik özellikleri açısından ise tanı süresi, $\mathrm{KY}$ evresini belirlemede kullanılan New York Heart Association (NYHA) evresi, Ejeksiyon Fraksiyon (EF) değeri, kalp pili-pacemaker kullanım durumu ve komorbid hastalıklarını kapsayan beş soru içerdi. Klinik özeliklere ilişkin bilgiler hastanın sağlık kayıtlarından, diğer sorular ise bakım veren aile üyelerinden öğrenilerek kayıt edildi. $[4,8,12,16,17,22,27]$

Bakım Veren Bilgi Formu: Literatür temel alınarak oluşturulan bakım veren aile üyelerinin özelliklerini inceleyen bu formda ise bakım verenlerin yaşı, cinsiyeti, eğitim durumu, medeni durum, çalışma durumu, ekonomik durumu, hastaya yakınlık derecesi, toplam bakım verme süresi ve günlük bakım verme saatini değerlendiren toplam dokuz soru yer aldı. $[14,16,27,28]$

Zarit Bakım Verme Yükü Ölçeği (ZBYÖ): Ölçek bakım verenler için Zarit ve ark. ${ }^{[29]}$ (1985) tarafından geliştirilmiş ve Cronbach alfa katsayısı 0.95 olarak hesaplanmıştır. Bakım gereksinimi olan bireye bakım verenlerin yaşadığı sıkıntıyı belirlemeyi amaçlayan bu ölçek toplam 22 ifade içermektedir. Ölçekte yer alan her bir ifade beşli Likert tipte $(0=$ hiçbir zaman, $1=$ =nadiren, $2=$ =bazen, $3=$ oldukça sık, $4=$ hemen her zaman) değerlendirilmektedir. Ölçekten en az 0 , en fazla 88 puan alınabilmektedir. Ölçek puanının yüksek olması, algılanan bakım verme yükünün yüksek olduğunu göstermektedir. Ölçeğin Türkçe geçerlik ve güvenirliği İnci ve Erdem $^{[30]}$ (2012) tarafından yapılmış, Cronbach alfa katsayısı 0.95 ve test-tekrar test değişmezlik katsayısı 0.90 olarak belirtilmiştir. Bu çalışmada ölçeğin Cronbach alfa katsayısı 0.81 olarak bulundu.

Araştırmanın Etik Yönü: Araştırmanın yapılabilmesi için girişimsel olmayan klinik araştırmalar etik kurulu onayı alındı (GO 18/1161). Etik kurul iznini takiben araştırmanın yürütülebilmesi için kurum izinleri alındı. Araştırma kriterlerine uyan bakım verenlerin dahil edilmesi için ikinci yazar, 20 Aralık 2018-3 Mayıs 2019 tarihleri arasında araştırmanın yürütüldüğü kurumun kliniklerine düzenli ziyaretler gerçekleştirdi. Bu sırada KY nedeni ile hastaneye başvuran hastaların bakım verenleri ile görüşüldü, araştırmanın ama$\mathrm{Cı}$ açıklandı ve araştırma hakkında detaylı bilgi aktarıldı. Bu bilgilendirme sonrası araştırmaya katılmaya gönüllü olan bakım veren aile üyeleri gönüllü olur formlarını onayladı.

Verilerin Toplanması: Veriler araştırmaya katılan bakım veren aile üyeleriyle hastadan ayrı bir ortamda yüz-yüze görüşme tekniği kullanılarak toplandı. Araştırmacı tarafından, bakım verenlere öncelikle bakım veren bilgi formu soruları yönlendirildi ve takiben ZBYÖ dolduruldu. Hastanın klinik özelliklerine ilişkin bilgiler ise hasta kayıtlarından alınarak kayıt edildi.

Verilerin Analizi: Verilerin istatistiksel analizi SPSS 23.0 programında yapıldı. Normal dağılıma uyan verilerin değerlendirilmesinde parametrik, uymayan verilerin değerlendirilmesinde ise nonparametrik testler kullanıldı. Araştırmada sosyo-demografik verilerin incelenmesinde yüzde, frekans, ortalama ve standart sapma gibi tanımlayıcı istatistikler kullanıldı. Hasta ve bakım verenlerin sosyo-demografik verileri ile ZBYÖ ölçeği arasındaki farklııkların değerlendirilmesinde Ki-Kare, Mann-Whitney U testi ve Kruskal Wallis testleri kullanıldı. Ayrıca hastaların KY tanı süresi, bakım verenlerin 
günlük bakım verme saati, toplam bakım verme süresi ile ZBYÖ puanları arasındaki ilişkinin değerlendirilmesi için Pearson korelasyon testi kullanıldı. İstatistik testlerde $p<0.05$ anlamlı olarak kabul edildi.

\section{Bulgular}

\section{Kalp Yetersizliği Hastalarının ve Bakım Verenlerin Tanımlayıcı Özellikleri}

Araştırmaya dahil olan KY hastalarının yaş ortalaması $66.76 \pm 12.43$ yıldır. Hastaların yarısından fazlası (\%55) erkek ve büyük bir kısmı (\%85) ilkokul mezunudur. Hastaların \%71'inin evli ve \%74'ünün gelir-gider durumunun eşit olduğu görülmüştür. Kalp yetersizliğine ilişkin bulgular ele alındığında, hastaların KY tanı süresi ortalaması 5.93 \pm 4.61 yıl olarak belirlenmiştir. NYHA sınıflamasına göre hastaların üçte birinden fazlasının (\%38) Evre 2, \%28'inin ise evre 3 KY olduğu görülmektedir. Hastaların EF değeri ortalaması $29.13 \pm 10.38$ olup, yaklaşık yarısı (\%49) destekleyici cihaz olarak pace-maker kullanmaktalardı. Kalp yetersizliği dışında eşlik eden komorbid durumlara bakıldığında, \%53'ünün 3'ün altında komorbid hastalığı olduğu bulunmuştur (Tablo 1). Hastaların çoğunda KY dışında komorbid hastalık bulunup; bunlar hipertansiyon (\%77), diyabetes mellitüs (\%50), hiperlipidemi (\%49), koroner arter hastalığı (\%21), aritmi (\%18) ve kronik obstrüktif akciğer hastalığı (\%17.0) şeklinde sıralanmıştır.

Bakım verenlerin sosyo-demografik verileri incelendiğinde ise yaş ortalamasının $50.74 \pm 12.68$ yıl olduğu belirlenmiştir. Bakım verenler çoğunlukla kadın (\%70) ve ilkokul (\%77) mezunu olup, neredeyse tamamı (\%99) evliydi. Ayrıca, bakım verenlerin \%76'sı herhangi bir işte çalışmadıklarını ve \%90'ı gelir-gider durumunun eşit olduğunu belirtmiştir. Bakım verenlerin \%47'si hastanın çocuğu ve \%46'sı da hastanın eşi olduğunu ifade etmiştir. Bakım verme süresi incelendiğinde ise bakım verenlerin yarıdan fazlasının (\%58) 5 yıl altında bakım verdiği, \%60'ının ise günlük bakım verme saatinin 5 saat üzerinde olduğu ortaya çıkmıştır (Tablo 1).

\section{Kalp Yetersizliği Hastalarının Klinik Özelliklerine Göre Algılanan Zarit Bakım Verme Yükü Ölçeği Puanları}

Hastaların KY tanı süreleri ile bakım verenlerin algıladıkları ZBYÖ puanları arasında pozitif yönde, zayıf bir ilişki olduğu belirlenmiştir ( $p<0.05$, Şekil 1). Hastaların EF değerleri ile ZBYÖ puanları arasındaki ilişkinin ise istatiksel açıdan anlamlı olmadığı tespit edilmiştir ( $p>0.05)$. Hastaların KY evresi ve komorbid hastalıkları ile bakım verenlerin ZBYÖ puanları arasındaki fark incelendiğinde, farkın istatistiksel açıdan anlamlı olduğu belirlenmiştir ( $p<0.05)$. Evre $1 \mathrm{KY}$ hastalarına bakım verenlerin ZBYÖ puan ortalamaları 11.16 \pm 6.21 ,

\begin{tabular}{|c|c|c|c|c|}
\hline \multirow{3}{*}{$\begin{array}{l}\text { Tanıtıcı özellikleri } \\
\text { Yaş (yıl) }\end{array}$} & \multicolumn{2}{|c|}{ Hasta } & \multirow{2}{*}{\multicolumn{2}{|c|}{$\begin{array}{l}\text { Bakım veren } \\
50.74 \pm 12.68\end{array}$}} \\
\hline & \multicolumn{2}{|c|}{$66.76 \pm 12.43$} & & \\
\hline & $\mathbf{n}$ & $\%$ & $\mathbf{n}$ & $\%$ \\
\hline \multicolumn{5}{|l|}{ Cinsiyet } \\
\hline Erkek & 55 & 55.0 & 30 & 30.0 \\
\hline Kadın & 45 & 45.0 & 70 & 70.0 \\
\hline \multicolumn{5}{|l|}{ Eğitim } \\
\hline İlköğretim & 85 & 85.0 & 77 & 77.0 \\
\hline Lise & 11 & 11.0 & 14 & 14.0 \\
\hline Lisans & 4 & 4.0 & 7 & 9.0 \\
\hline \multicolumn{5}{|l|}{ Medeni durum } \\
\hline Evli & 71 & 71.0 & 99 & 99.0 \\
\hline Dul & 29 & 29.0 & 1 & 1.0 \\
\hline \multicolumn{5}{|l|}{ Ekonomik durum } \\
\hline Gelir, giderden az & 23 & 23.0 & 8 & 8.0 \\
\hline Gelir, gidere eşit & 74 & 74.0 & 90 & 90.0 \\
\hline Gelir, giderden fazla & 3 & 3.0 & 2 & 2.0 \\
\hline \multicolumn{5}{|l|}{ NYHA evresi } \\
\hline Evre 1 & 18 & 18.0 & & \\
\hline Evre 2 & 38 & 38.0 & & \\
\hline Evre 3 & 28 & 28.0 & & \\
\hline Evre 4 & 16 & 16.0 & & \\
\hline Hastalık süresi (yıl) & \multicolumn{2}{|c|}{$5.93 \pm 4.61$} & & \\
\hline Ejeksiyon fraksiyon (EF), \% & \multicolumn{2}{|c|}{$29.13 \pm 10.38$} & & \\
\hline \multicolumn{5}{|l|}{ Pacemaker kullanımı } \\
\hline Evet & 49 & 49.0 & & \\
\hline Hayır & 51 & 51.0 & & \\
\hline \multicolumn{5}{|l|}{ Komorbidite } \\
\hline$\leq 3$ & 53 & 53.0 & & \\
\hline$\geq 3$ & 47 & 47.0 & & \\
\hline \multicolumn{5}{|l|}{ Çalışma durumu } \\
\hline Çalışmıyor & & & 76 & 76.0 \\
\hline Çalışıyor & & & 24 & 24.0 \\
\hline \multicolumn{5}{|l|}{ Yakınlık derecesi } \\
\hline Çocuğu & & & 47 & 47.0 \\
\hline Eşi & & & 46 & 46.0 \\
\hline Diğer & & & 7 & 7.0 \\
\hline \multicolumn{5}{|l|}{ Bakım verme süresi (yıl) } \\
\hline$<5$ & & & 58 & 58.0 \\
\hline $5-8$ & & & 28 & 28.0 \\
\hline$>8$ & & & 14 & 14.0 \\
\hline \multicolumn{5}{|l|}{ Günlük bakım verme saati } \\
\hline$\leq 5$ & & & 40 & 40.0 \\
\hline$>5$ & & & 60 & 60.0 \\
\hline
\end{tabular}

n: Katılımcı sayısı; Ort: Ortalama; SS: Standart sapma.

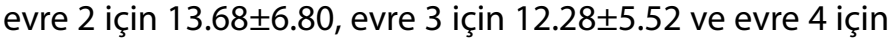
ise $19.12 \pm 7.62$ olarak tespit edilmiştir. Hastaların komorbid durumları açısından incelendiğinde ise 3 'ün altında komorbid hastalığı olan KY hastalarına bakım verenlerin ZBYÖ puan ortalaması $11.58 \pm 5.93,3$ ve üstünde komorbid duru- 


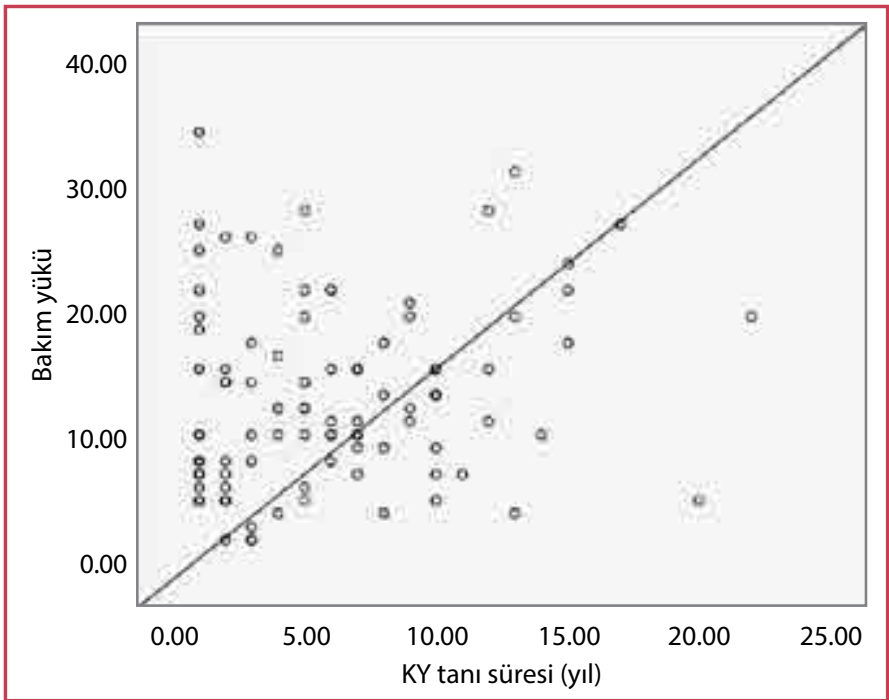

Şekil 1. Kalp yetersizliği tanı süresi ile zarit bakım verme yükü ölçeği arasındaki korelasyon.

mu olan hastalara bakım verenlerde ise $16.10 \pm 7.17$ olduğu belirlenmiştir. Hastaların pacemaker kullanım durumları ile bakım verenlerin ZBYÖ puanları arasındaki fark ise istatistiksel olarak anlamlı bulunmamıştır ( $p>0.05$; Tablo 2).

\section{Bakım Verenlerin Sosyo-Demografik Özelliklerine Göre Algıladıkları Zarit Bakım Verme Yükü Ölçeği Puanları}

Bakım verenlerde algılanan bakım yükü değerlendirildiğinde ZBYÖ puan ortalamasının $13.71 \pm 6.89$ olduğu he-

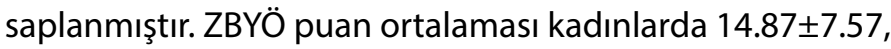
erkeklerde $10.10 \pm 6.07$ olarak bulunmuş ve gruplar arasında istatistiksel olarak anlamlı bir fark tespit edilmemiştir ( $p>0.05)$. Bakım veren aile üyelerinin eğitim durumları ve

\begin{tabular}{|c|c|c|c|}
\hline Tanıtıcı Özellik & $\begin{array}{c}\text { ZBYÖ } \\
\text { Ort土SS }\end{array}$ & Test İstatistiği & $\mathbf{p}$ \\
\hline Hastalık süresi (yıl) & & $0.199 *$ & 0.047 \\
\hline Ejeksiyon fraksiyon (EF), \% & & $0.006^{*}$ & 0.955 \\
\hline \multicolumn{4}{|l|}{ NYHA evresi } \\
\hline Evre 1 & $11.16 \pm 6.21$ & $* *$ & \multirow{4}{*}{0.009} \\
\hline Evre 2 & $13.68 \pm 6.80$ & \multirow{3}{*}{11.602} & \\
\hline Evre 3 & $12.28 \pm 5.52$ & & \\
\hline Evre 4 & $19.12 \pm 7.62$ & & \\
\hline \multicolumn{4}{|l|}{ Pacemaker kullanımı } \\
\hline Evet & $14.08 \pm 6.92$ & $* * *$ & \multirow{2}{*}{0.507} \\
\hline Hayır & $13.35 \pm 6.91$ & -0.663 & \\
\hline \multicolumn{4}{|l|}{ Komorbidite } \\
\hline 3 altı & $11.58 \pm 5.93$ & $* * *$ & \multirow{2}{*}{0.001} \\
\hline 3 ve üstü & $16.10 \pm 7.17$ & -3.221 & \\
\hline
\end{tabular}

n: Katılımcı sayısı; Ort: Ortalama; SS: Standart sapma; *Pearson korelasyon test değeri; ${ }^{* *}$ Kruskal-Wallis test değeri; ${ }^{* * *}$ Mann-Whitney U test değeri.

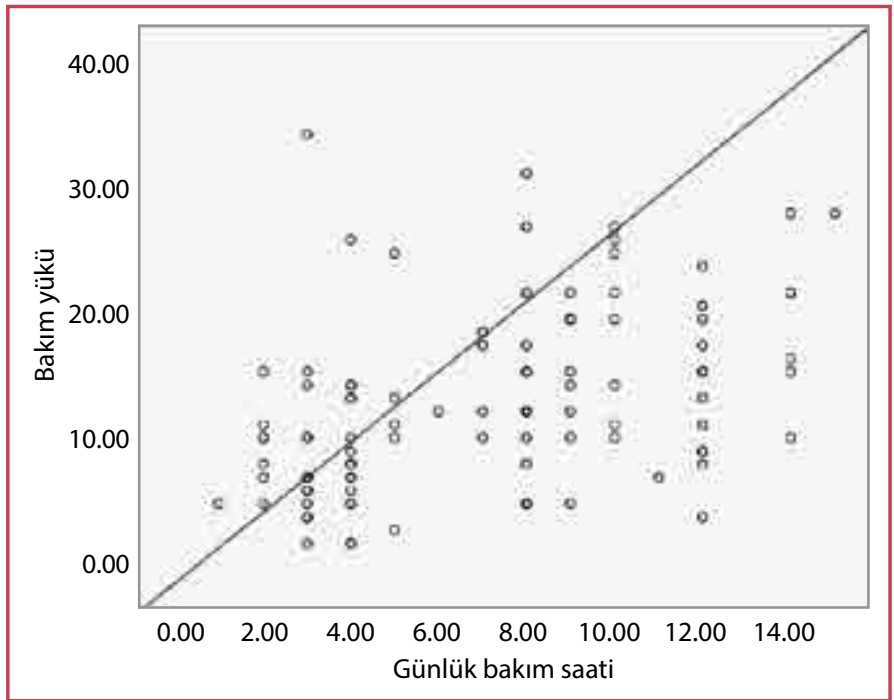

Şekil 2. Günlük bakım saati ile Zarit Bakım Verme Yükü Ölçeği arasındaki korelasyon.

ZBYÖ puan ortalamaları arasındaki fark ele alındığında istatistiksel olarak anlamlı bir fark olduğu bulunmuştur $(p<0.05)$. Ekonomik duruma bakıldığında gelir durumu gider durumundan az olanlarda ZBYÖ puan ortalaması $22.37 \pm 10.58$, eşit olanlarda $12.85 \pm 6.59$, fazla olanlarda ise $4.0 \pm 1.41$ olarak tespit edilmiş ve bu farkın istatistiksel olarak anlamlı olduğu sonucuna ulaşıımıştır $(p<0.05)$. Çalışmayan bakım verenlerde ZBYÖ puan ortalaması 14.65 \pm 7.72 , çalışanlarda ise $9.58 \pm 4.91$ olup istatistiksel olarak anlamlı bir fark olduğu belirlenmiş̧ir $(p<0.05)$. Günlük bakım verme saati ele alındığında 5 saat altında bakım verenlerde ZBYÖ puan ortalaması $9.80 \pm 5.67,5$ saat üzerinde bakım verenlerde ise $15.86 \pm 7.55$ olarak hesaplanmış ve gruplar arasında istatistiksel olarak anlamlı bir fark bulunmuştur $(p<0.05$, Şekil 2). Toplam bakım verme süresi 5 yıl altında olanlarda ZBYÖ puan ortalaması $11.15 \pm 6.88,5$ ve 8 yıl arasında olanlarda $16.24 \pm 7.44$ ve 8 yıl üstünde olanlarda ise $16.92 \pm 6.79$ olarak belirlenmiş ve gruplar arasındaki farkın istatistiksel olarak anlamlı olduğu tespit edilmiştir $(p<0.05$; Şekil 3; Tablo 3).

\section{Tartışma}

KY giderek artan önemli morbidite ve mortalitesi olan kronik bir hastalık olması nedeniyle hem hastalara hem de bakım veren aile üyelerine önemli zorluklar getirmektedir. Bu açıdan, KY hastasına bakım veren aile üyelerinin bakım sürecinde yaşadıkları sorunların ele alınması, bakım yükünün ise ölçüm araçlarının kullanımı ile ortaya konması önem arz etmektedir. Bu çalışmada, ülkemizde ilk defa KY tanılı hastalara bakım veren aile üyelerinin algıladıkları bakım yükü incelenmiştir. Araştırmamızda bakım verenlerin ZBYÖ orta- 


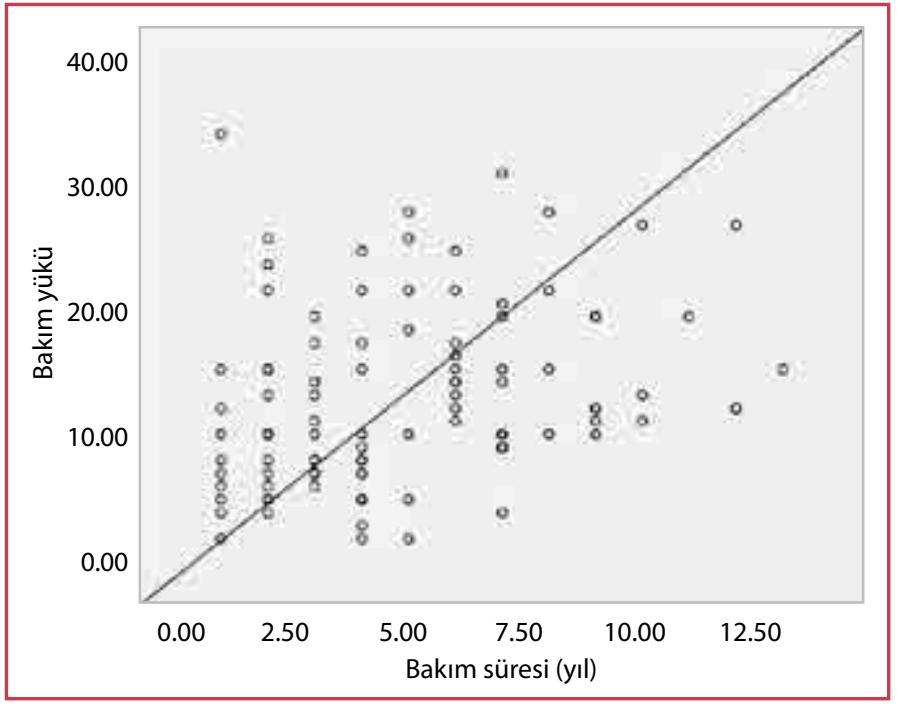

Şekil 3. Toplam bakım süresi ile zarit bakım verme yükü ölçeği arasındaki korelasyon.

\begin{tabular}{|c|c|c|c|}
\hline Tanıtıcı Özellik & $\begin{array}{c}\text { ZBYÖ } \\
\text { Ort } \pm S S\end{array}$ & Test İstatistiği & $\mathbf{p}$ \\
\hline \multicolumn{4}{|l|}{ Yaş } \\
\hline $0-50$ & $12.59 \pm 6.21$ & $*$ & \multirow{2}{*}{0.623} \\
\hline$>50$ & $14.43 \pm 8.36$ & -0.623 & \\
\hline \multicolumn{4}{|l|}{ Cinsiyet } \\
\hline Kadın & $14.87 \pm 7.57$ & * & \multirow{2}{*}{0.214} \\
\hline Erkek & $10.10 \pm 6.07$ & -1.244 & \\
\hline \multicolumn{4}{|l|}{ Eğitim } \\
\hline Illköğretim & $13.10 \pm 6.22$ & ** & \multirow{4}{*}{$<0.001$} \\
\hline Lise & $15.28 \pm 6.77$ & 18.580 & \\
\hline Lisans & $5.50 \pm 0.70$ & & \\
\hline Lisansüstü & $17.60 \pm 10.99$ & & \\
\hline \multicolumn{4}{|l|}{ Medeni durum } \\
\hline Evli & $13.46 \pm 7.49$ & $* *$ & \\
\hline Bekar & & 1.273 & 0.259 \\
\hline \multicolumn{4}{|l|}{ Ekonomik durum } \\
\hline Gelir, giderden az & $22.37 \pm 10.58$ & $* *$ & \multirow{3}{*}{0.005} \\
\hline Gelir, gidere eşit & $12.85 \pm 6.59$ & 10.472 & \\
\hline Gelir, giderden fazla & $4.0 \pm 1.41$ & & \\
\hline \multicolumn{4}{|l|}{ Çalışma durumu } \\
\hline Çalışmıyor & $14.65 \pm 7.72$ & * & \multirow{2}{*}{0.006} \\
\hline Çalışıyor & $9.58 \pm 4.91$ & -2.752 & \\
\hline \multicolumn{4}{|l|}{ Yakınlık derecesi } \\
\hline Çocuğu & $13.40 \pm 6.33$ & $* *$ & \\
\hline Eşi & $13.73 \pm 8.52$ & 0.560 & 0.756 \\
\hline Diğer & $11.71 \pm 7.78$ & & \\
\hline \multicolumn{4}{|l|}{ Bakım verme süresi } \\
\hline$<5$ & $11.15 \pm 6.88$ & $* *$ & \\
\hline $5-8$ & $16.24 \pm 7.44$ & 14.375 & 0.001 \\
\hline$>8$ & $16.92 \pm 6.79$ & & \\
\hline \multicolumn{4}{|l|}{ Günlük bakım verme saati } \\
\hline$\leq 5$ & $9.80 \pm 5.67$ & * & \\
\hline$>5$ & $15.86 \pm 7.55$ & -4.024 & $<0.001$ \\
\hline
\end{tabular}

n: Katılımcı sayısı; Ort: Ortalama; SS: Standart sapma; *Mann-Whitney U test değeri; ** Kruskal-Wallis test değeri. lama puanının $13.71 \pm 6.89$, düşük düzeyde olduğu ortaya çıkmıştır. Saunders (2008), ${ }^{[18]}$ KY tanılı hastalara bakım verenlerin algıladıkları bakım yükünü incelediği çalışmasında bulgumuza paralel olarak bakım verenlerde düşük-orta düzeyde bakım yükü olduğunu belirlemiştir. Agren ve ark. (2010), ${ }^{[23]}$ KY hastalarına bakım veren eşlerin algıladıkları bakım yükünü inceledikleri başka bir çalışmada da bakım verenlerin üçte ikisinde bakım yükünün düşük düzeyde olduğunu bildirmişlerdir. Bulgularımızın aksine Luttik ve ark.'nın (2010) ${ }^{[15]}$ son dönem KY tanılı hastalara bakım veren eşlerin bakım yükünü değerlendirdikleri başka bir çalışmada bakım verenlerin algıladıkları bakım yükünün diğer çalışmalara göre daha yüksek olduğu vurgulanmıştır. Ülkemizde KY tanılı hastalardan oluşan ve bakım veren aile üyelerinin algıladıkları bakım yükünü inceleyen benzer bir araştırma olmadığı için bulgular arasında direk karşılaştırma yapmak mümkün olamamıştır. Öte yandan bulgulardaki farklııı̆ın, araştırma örneklemimizdeki bakım yükünün düşük düzeyde belirlenmesinin hastaların çoğunluğunun evre $2 \mathrm{KY}$ tanılı olması ve bu nedenle günlük bakım ihtiyaçlarının çoğunluğunu kendilerinin karşılayabilmesi ile ilgili olabileceği düşünülmüştür. Bulgulardaki farklılığın bir nedeninin de ülkemizde bakım verme kavramının aile üyeleri tarafından rutin bir görev olarak algılanması ve toplumsal, kültürel değerlerle de ilgili olabileceği, bu nedenle bakım verenlerin algıladıkları bakım yükünün görece düşük olabileceği öngörülmüştür. ${ }^{[31]}$

Literatürde $K Y$ tanılı hastalara bakım veren a aile üyelerinin algıladıkları bakım yükünü hastaların klinik özelliklerinin de etkileyebileceği bildirilmiştir. KY hastalarında bakım verme yükünü inceleyen önceki araştırma sonuçları incelendiğinde KY tanı süresi, KY evresi, hastanın EF değeri, eşlik eden komorbid durumları ve fiziksel kapasitesindeki sınırlılıklar gibi durumların bakım yüküne doğrudan etkisinin olabileceği rapor edilmiştir. ${ }^{[10,19,23]}$ Çalışmamızda KY hastalarının klinik özellikleri ile bakım verenlerin algıladıkları ZBYÖ puanları arasındaki farklar incelendiğinde, hastaların tanı süreleri uzadıkça, evresi ve komorbid hastalık sayıları arttıkça bakım verenlerin de daha yüksek düzeyde bakım yükü algıladıkları belirlenmiştir. Öte yandan hastaların EF değeri ve pacemaker gibi destekleyici cihaz kullanım durumlarının bakım verme yükünü anlamlı düzeyde etkilemediği sonucuna ulaşılmıştır. Çalışma bulgularımıza benzer şekilde, Hooley ve ark. ${ }^{[20]}$ (2005) yaptıkları bir çalışmada KY hastalarının eşlik eden komorbid durumlarının bakım yükünü artırdığı bildirmiştir. Agren ve ark. ${ }^{[23]}$ (2010) da hastaların fiziksel durumları kötüleştikçe algılanan bakım yükünün arttığını bildirmiştir. Bulgularımızı destekler şekilde, Luttik ve ark. (2010) ve Karmilovich (1994) KY hastalarının EF de- 
ğeri ile algılanan bakım yükü arasında anlamlı bir ilişkinin olmadığını belirlemişlerdir. ${ }^{[12,15]}$ Araştırmamızda, önceki çalışma sonuçlarını doğrular şekilde KY tanı süresinin uzamasının, beraberinde bakım verenlerin bakım verme süresini de doğrudan etkileyebileceği, evre ilerledikçe artan semptom yükü ve fiziksel kısıtılıkların hastaların bakımda başkalarının desteğine daha fazla gereksinim duymasına neden olabileceği ve böylelikle algılanan bakım yükünün artışına yol açabileceği düşünülmüştür.

Kalp yetersizliği tanılı hastalarda bakım yükü üzerinde etkili olabileceği bildirilen diğer faktörler ise bakım verenlerle ilişkilendirilmiştir. Literatürde bakım verenlerin yaşı, cinsiyeti, eğitim düzeyi, çalışma durumu, gelir durumu, bakım verdiği hastaya yakınlık derecesi, hastanın günlük yaşam aktivitelerinde desteğe gereksinim duyması, başka birilerine de bakım vermesi, depresyon sorunu olması, toplam bakım verme süresi ve gün içinde bakım verdiği saat gibi durumların algılanan bakım verme yükünü etkileyebileceği bildirilmiştir. ${ }^{[15-18,23]}$ Araştırmamızda bakım verenlerin yaşı, cinsiyeti ve hastaya yakınlık derecesi ve yaşadıkları yer ile ZBYÖ puanları arasındaki fark anlamIı bulunmamıştır. Öte yandan, eğitim durumu, çalışma durumu, gelir durumu, gün içinde bakım verme saati ve toplam bakım verme süresi değişkenleri ile ZBYÖ puanları arasındaki farkın istatistiksel açıdan anlamlı olduğu bulunmuştur. Çalışmamızda eğitim seviyesi düşük, herhangi bir işte çalışmayan, gelir durumu düşük, hastasına günde 5 saatten fazla ve 8 yıldan daha uzun süredir bakım veren aile üyelerinde algılanan ZBYÖ puanlarının anlamlı düzeyde yüksek olduğu ortaya çıkmıştır. Çalışmamızda cinsiyet açısından algılanan ZBYÖ puanları dikkatle incelendiğinde kadın bakım verenlerin ZBYÖ ortalama puanları daha yüksek bulunsa da farkın anlamlı olmadığı belirlenmiştir. Luttik ve ark. ${ }^{[15]}$ (2010) bulgumuzu destekler şekilde cinsiyet ile bakım yükü arasındaki ilişkinin anlamlı olmadığını bildirmişlerdir. Bu bulguların aksine, literatürde kadın bakım verenlerin bakım verme sürecinde daha fazla zorlandıkları, duygusal açıdan iyilik hallerinin azaldığı, daha fazla sosyal desteğe gereksinim duydukları ve bakım yükünü daha fazla hissettiklerini bildiren çalışmalar da bulunmaktadır. [27, 32, 33] Saunder (2008) ${ }^{[18]}$ çalışmasında bakım verenlerin daha yaşlı olması, KY hastası dışında başka bireylere de bakım vermesi, eşlik eden komorbid durumlarının fazla olması, bakım verme süresinin uzun olması gibi durumların yüksek bakım yükü ile anlamlı şekilde ilişkili olduğunu belirtmiştir. Agren ve ark. (2010) ${ }^{[23]}$ çalışmalarında fiziksel ve psikososyal sağlık sorunları olan bakım verenlerin bakım yükünü daha fazla algıladığını bildirmiştir.

\section{Sonuç}

Araştırma bulguları dikkate alındığında, bu çalışma ile KY tanılı hastalara bakım veren aile üyelerinin algıladıkları bakım yükünün belirlenmesi ile literatüre önemli katkı sağlanmıştır. Bulgular incelendiğinde akılda tutulması gereken temel nokta, kadınların, çalışmayanların, eğitim seviyesi ve gelir durumu düşük olanların, hem toplam bakım verme süresi hem de günlük bakım verme saati uzun olanların daha fazla bakım yükü yaşadıklarının ortaya konmasıdır. Bu bulgulardan hareketle, KY hastalarına bakım veren aile üyelerini destekleyici nitelikte yapılacak ilerideki eğitim ve müdahale araştırmalarında özellikle bu hassas grupların gereksinimleri doğrultusunda planlamaların yapılması öncelik arz etmektedir.

\section{Teşekkür}

Bu araştırmanın gerçekleştirilmesinde gönüllü olarak katkı veren tüm bakım veren aile üyelerine içtenlikle teşekkür ederiz. Ayrıca, Hacettepe Üniversitesi Hemşirelikte Eğitim, Uygulama ve Araştırma Merkezine sağladıkları desteklerden dolayı gönülden minnettarız.

Etik Kurul Onayı: Hacettepe Üniversitesi Girişimsel Olmayan Araştırmalar Etik Kurulu'ndan, GO 18/1161 kodu ile 11 Aralık 2018 tarihinde etik kurul izni alınmıştır.

Hakem Değerlendirmesi: Dış bağımsız.

Çıkar Çatışması: Yazarlar arasında herhangi bir çıkar çatışması bulunmamaktadır.

Yazarlık Katkıları: Konsept: Z.G.M., A.H.; Dizayn: Z.G.M., A.H.; Veri Toplama veya Işleme: A.H., Z.G.M.; Analiz veya Yorumlama: Z.G.M., A.H.; Literatür Arama: Z.G.M., A.H.; Yazan: Z.G.M., A.H.

\section{Kaynaklar}

1. Degertekin M, Erol Ç, Ergene O, Tokgözoğlu L, Aksoy M, Erol $M K$, et al. Heart failure prevalence and predictors in Turkey: HAPPY study. Archives of the Turk Kardiyol Dern Ars 2012;40:298-308.

2. Ponikowski P, Voors AA, Anker SD, Bueno H, Cleland JG, Coats AJ, et al. 2016 ESC Guidelines for the diagnosis and treatment of acute and chronic heart failure: The Task Force for the diagnosis and treatment of acute and chronic heart failure of the European Society of Cardiology (ESC). Developed with the special contribution of the Heart Failure Association (HFA) of the ESC. Eur J Heart Fail 2016;18:891-975.

3. Benjamin EJ, Blaha MJ, Chiuve SE, Cushman M, Das SR, Deo $R$, et al. Heart disease and stroke statistics-2017 update: a report from the American Heart Association. Circulation 2017;135:e146-e603.

4. Conley S, Feder S, Redeker NS. The relationship between pain, fatigue, depression and functional performance in stable heart failure. Heart Lung 2015;44:107-12.

5. Alpert CM, Smith MA, Hummel SL, Hummel EK. Symptom burden in heart failure: assessment, impact on outcomes, and 
management. Heart Fail Rev 2017;22:25-39.

6. Gallacher K, May CR, Montori VM, Mair FS. Understanding patients' experiences of treatment burden in chronic heart failure using normalization process theory. Ann of Fam Med 2011;9:235-43.

7. Garin O, Herdman M, Vilagut G, Ferrer M, Ribera A, Rajmil L, et al. Assessing health-related quality of life in patients with heart failure: a systematic, standardized comparison of available measures. Heart Fail Rev 2014;19:359-67.

8. Rogers JG, Aaronson KD, Boyle AJ, Russell SD, Milano CA, Pagani FD, et al. Continuous flow left ventricular assist device improves functional capacity and quality of life of advanced heart failure patients. J Am Coll Cardiol 2010;55:1826-34.

9. Staniute M, Brozaitiene J, Burkauskas J, Kazukauskiene N, Mickuviene N, Bunevicius R. Type D personality, mental distress, social support and health-related quality of life in coronary artery disease patients with heart failure: a longitudinal observational study. Health Qual Outcomes 2015;13:1-11.

10. Molloy GJ, Johnston DW, Witham MD. Family caregiving and congestive heart failure. Review and analysis. European journal of heart failure 2005;7:592-603.

11. Hwang B, Fleischmann K, Howie-Esquivel J, Stotts N, Dracup K. Caregiving for Patients With Heart Failure: Impact on $\mathrm{Pa}$ tients' Families. Am J Crit Care 2011;20:431-41.

12. Karmilovich SE. Burden and stress associated with spousal caregiving for individuals with heart failure. Prog Cardiovasc Nurs 1994;9:33-8.

13. Dionne-Odom JN, Hooker SA, Bekelman D, Ejem D, McGhan G, Kitko $L$, et al. Family caregiving for persons with heart failure at the intersection of heart failure and palliative care: a state-of-the-science review. Heart Fail Rev 2017;22:543-57.

14. Kang X, Li Z, Nolan MT. Informal caregivers' experiences of caring for patients with chronic heart failure: systematic review and metasynthesis of qualitative studies. J Cardiovasc Nurs 2011;26:386-94.

15. Luttik ML, Jaarsma T, Veeger N, Tijssen J, Sanderman R, Van Veldhuisen DJ. Caregiver burden in partners of Heart Failure patients; limited influence of disease severity. Eur J Heart Fail 2007;9:695-701.

16. Hu X, Dolansky MA, Hu X, Zhang F, Qu M. Factors associated with the caregiver burden among family caregivers of patients with heart failure in southwest China. Nurs Health Sci 2016;18:105-12.

17. Bahrami M, Etemadifar S, Shahriari M, Farsani AK. Caregiver burden among Iranian heart failure family caregivers: A descriptive, exploratory, qualitative study. Iran J Nurs Midwifery Res 2014;19:56-63.

18. Saunders MM. Factors associated with caregiver burden in heart failure family caregivers. West J Nurs Res 2008;30:943-59.

19. Özer S. Kalp Yetersizliğinde Aile/Bakım Verici Yükü. Turk J Card Nur 2010;1:3-7.

20. Hooley PJ, Butler G, Howlett JG. The relationship of quality of life, depression, and caregiver burden in outpatients with congestive heart failure. Congest Heart Fail 2005;11:303-10.

21. Selçuk KT, Avcı D. Kronik hastalığa sahip yaşlılara bakım verenlerde bakım yükü ve etkileyen etmenler. SDÜ Sağlık Bilimleri Dergisi 2016;7:1-9.

22. Janssen DJ, Spruit MA, Wouters EF, Schols JM. Family caregiving in advanced chronic organ failure. J Am Med Dir Assoc 2012;13:394-9.

23. Agren S, Evangelista L, Strömberg A. Do partners of patients with chronic heart failure experience caregiver burden? Eur J Cardiovasc Nurs 2010;9:254-62.

24. Buck HG, Harkness K, Wion R, Carroll SL, Cosman T, Kaasalainen $\mathrm{S}$, et al. Caregivers' contributions to heart failure self-care: a systematic review. Eur J Cardiovasc Nurs 2015;14:79-89.

25. Şirzai H, Delialioğlu SÜ, Sarı IF, Özel S. İnme ve Bakım Verme Yükü. Fiziksel Tıp ve Rehabilitasyon Bilimleri Dergisi 2015;18:162-9.

26. Yildirim S, Engin E, Baskaya VA. The Burden of Caregivers of Stroke Patients and the Factors Affecting the Burden. [Article in Turkish]. Archives of Neuropsychiatry 2013;50:169-74.

27. Evangelista LS, Dracup K, Doering L, Westlake C, Fonarow GC, Hamilton M. Emotional well-being of heart failure patients and their caregivers. J Card Fail 2002;8:300-5.

28. Pressler SJ, Gradus-Pizlo I, Chubinski SD, Smith G, Wheeler S, Sloan R, et al. Family caregivers of patients with heart failure: a longitudinal study. J of Cardiovasc Nurs 2013;28:417-28.

29. Schreiner AS, Morimoto T, Arai Y, Zarit S. Assessing family caregiver's mental health using a statistically derived cutoff score for the Zarit Burden Interview. Aging Ment Health 2006;10:107-11.

30. Ozer N, Yurttaş A, Akyil RÇ. Psychometric evaluation of the Turkish version of the Zarit Burden Interview in family caregivers of inpatients in medical and surgical clinics J Transcult Nurs 2012;23:65-71.

31. Gok Metin Z, Karadas C, Balci C, Cankurtaran M. The Perceived Caregiver Burden Among Turkish Family Caregivers Providing Care for Frail Older Adults. J Transcult Nurs 2019;30:222-30.

32. Rohrbaugh MJ, Cranford JA, Shoham V, Nicklas JM, Sonnega JS, Coyne JC. Couples coping with congestive heart failure: Role and gender differences in psychological distress. J Fam Psychol 2002;16:3-13.

33. Yee JL, Schulz R. Gender differences in psychiatric morbidity among family caregivers: A review and analysis. Gerontologist 2000;40:147-64.

34. Küçükgüçlü Ö, Şentürk Gönen S, Söylemez Akpınar B. Alzheimer Hastalığı Olan Bireye Bakım Veren Aile Üyelerinin Bakım Verme Sürecindeki Deneyimleri. Dokuz Eylül Üniversitesi Hemşirelik Fakültesi Elektronik Dergisi 2017;10:68-78.

35. Chiao CY, Wu HS, Hsiao CY. Caregiver burden for informal caregivers of patients with dementia: A systematic review. Int Nurs Rev 2015;62:340-50.

36. Olai L, Borgquist L, Svärdsudd K. Life situations and the care burden for stroke patients and their informal caregivers in a prospective cohort study. Ups J Med Sci 2015;120:290-8. 